\title{
The Rule of Law, Legal Pluralism, and Challenges to a Western-centric View: Some Very Preliminary Observations
}

Peer Zumbansen

Osgoode Hall Law School of York University, pzumbansen@osgoode.yorku.ca

Follow this and additional works at: http:// digitalcommons.osgoode.yorku.ca/olsrps

Part of the Law Commons

\section{Recommended Citation}

Zumbansen, Peer, "The Rule of Law, Legal Pluralism, and Challenges to a Western-centric View: Some Very Preliminary Observations" (2017). Osgoode Legal Studies Research Paper Series. 193.

http://digitalcommons.osgoode.yorku.ca/olsrps/193 
The Dickson Poon School of Law

SomersetHouse EastWing

Strand, London, WC2R 2LS

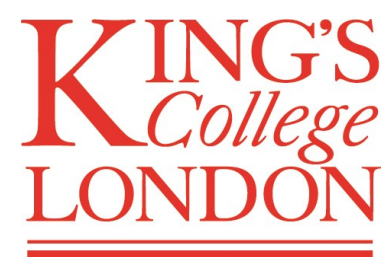

\section{The Rule of Law, Legal Pluralism, and Challenges to a Western-centric View: Some Very Preliminary Observations}

Peer Zumbansen

King's College London Dickson Poon School of Law

Legal Studies Research Paper Series: Paper No. 2017-05 

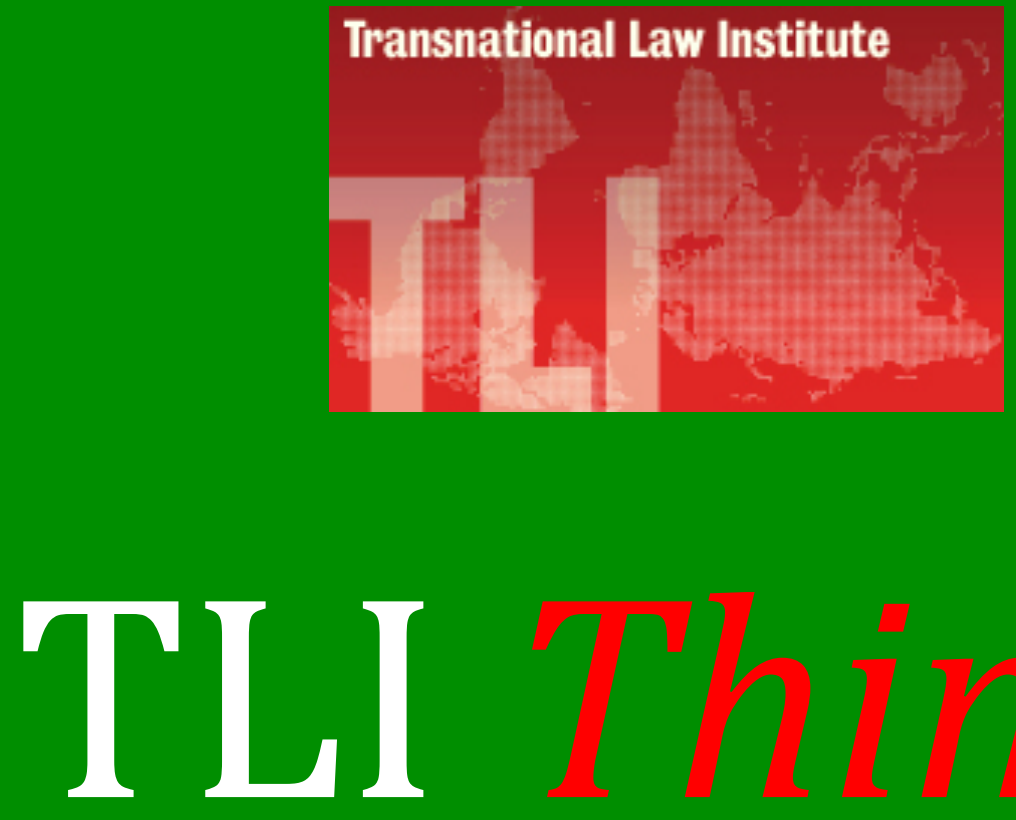

A Dickson Poon Transnational Law Institute, King's College London Research Paper Series

The Rule of Law, Legal Pluralism, and Challenges to a Westerncentric View: Some Very Preliminary Observations

\section{Peer Zumbansen}

\section{TLI $\quad$ Paper $47 / 2016$}

Editor: Peer Zumbansen, Director TLI / Managing Editor: Dayan Farias Picon

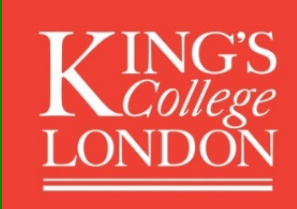

The Dickson Poon School of Law, King's College London

W: http://www.kcl.ac.uk/law/tli E: tli@kcl.ac.uk

This paper can be downloaded without charge at https://ssrn.com/abstract $=2869190$ 
Abstract: Despite hundreds of "Rule of Law" projects at the World Bank and a host of research into the foundations and content of the Rule of Law, we are still nowhere near an altogether satisfactory definition. While the Rule of Law is repeatedly being referred to in 'legal assistance' and 'law reform' projects and lives as a guiding principle in constitutions around the world, we don't seem able to settle on a commonly agreedupon approach to its nature and institutional form. In this context, the Rule of Law provides an opportunity to engage critically with the differences in perception and bias from which participants in the debate define and situate the principle and its underlying values. This short paper argues for a legal pluralist understanding of the Rule of Law as a set of selective institutional experiences and normative contentions which look very different when studied across time and space. Complementing some of the work that has been done in post-colonial studies and by TWAIL (Third World Approaches to International Law) scholars in law, the 'transnationalization of the rule of law' might be one of the important next frontiers in deconstructing Western and Northern narratives of legal ordering.

Keywords: Rule of Law, Legal Pluralism, Post-colonialism, World Bank, Orientalism, Legal Transplants, Empire.

\section{Institutional affiliation:}

\section{Peer Zumbansen}

Director, Transnational Law Institute [TLI]

Faculty Co-Convener, Transnational Law Summer Institute [TLSI]

The Dickson Poon School of Law

King's College London

Strand, London WC2R 2LS

United Kingdom

Email: tli@kcl.ac.uk / peer.zumbansen@kcl.ac.uk 


\title{
The Rule of Law, Legal Pluralism, and Challenges to a Western-centric View: Some Very Preliminary Observations
}

\author{
Peer Zumbansen
}

"Pluralism is most often used in a political context, to describe a state in which many voices and opinions, and in particular political groupings, are able to co-exist. This is possible in politics because a choice for one group - an election - simply entails that the others lose power, not that they cease to exist. This translates rather uncomfortably to law. A law, or judicial decision, renders other views legally irrelevant. A legal system, unlike a pluralist political system, does not aim at maintaining the coexistence of diverse opinions, but rather at ending this state of affairs, in the name of legal certainty and authority. One may ask whether law can be, or even should be, pluralist." 1

\section{The Slippery Nature of the Rule of Law}

Which signals must we heed in search of assessing and ascertaining the current state of the 'rule of law'? Are we to look for instances of triumphant rescue or of tragic failure of the concept? Must we be on the look-out for judicial pronouncements, legislative advances or administrative orders to test the rule of law's current temperature and mode of operation? Is it sufficient to apply a public law lens in order to seek out the institutional and procedural forms of the rule of law's modes of existence and their possible transformations in a world marked by globalisation, privatization and attending shifts between governmental regulatory prerogative and the market's claims to 'self-rule'? Or, ought we to include contractual and corporate governance developments, both still under the auspices of private law, when we attempt to depict

\footnotetext{
King's College London. This chapter has benefitted from generous comments and feedback from Daniel Drache and Jothie Rajah. I am furthermore very grateful for conversations with Harry Arthurs on the use of the term 'rule of law' in the present-day context and indebted to the editors of this volume, Christopher May and Adam Winchester for very helpful guidance in finalizing the paper.

1 Gareth Davies, What is a pluralist legal system, and is the EU one?, manuscript on file with author, available at: www3.law.ox.ac/denning-archive/news/events-files/Davies-2.pdf.
} 
the contours of far-reaching deregulations and the rise of private regulatory regimes in both industry and former public service areas? When studying the rule of law 'in action', its mode of generating knowledge and processing information, its instruments of 'control', of surveillance and intervention - how does a traditional constitutional or administrative rule of law perspective apply to the increasingly dominant role played by private companies exercising near-to-complete control over data flows? ${ }^{2}$ Where, in the inherited model of constitutional supremacy and separation of powers are we to account for the expansion of private arbitration tribunals in charge of settling investment disputes between sovereign states and multinationals? ${ }^{3}$ Who is in charge, in other words, who is responsible and competent to care for the hundreds of thousands of displaced persons today, refugees, uprooted and set adrift? What sense does it make to speak of a rule of law, when we are no longer confident from which vantage point to define 'citizenship', 'home', 'belonging'?4 How are we to interpret momentous instances, regarding their far-reaching impact, despite their local occurrence? What is the longterm significance of the much anticipated decision of the UK High Court regarding parliamentary approval of the government's triggering of Article 50 of the Treaty of the European Union ${ }^{5}$ or the outcome of the 2016 presidential election in the United States? ${ }^{6}$ And, from which vantage point and perspective are such assessments to be made?

Not only, then, are the challenges confronting an aspirationally open-minded and critical engagement with the rule of law political and geographical, but also definitional. There are, arguably, only a few other categories, concepts or ideas for lawyers as heavily

\footnotetext{
2 Shoshana Zuboff, Big other: surveillance capitalism and the prospects of an information civilization, 30 Journal of Information Technology 75 (2015).

${ }^{3}$ Gus van Harten, Investment Treaty Arbitration and Public Law (2006); MS Sornarajah, Resistance and Change in the International Law on Foreign Investment (2015).

${ }^{4}$ Zumbansen, How, Where and for Whom? Interrogating Law's Forms, Locations and Purposes, Inaugural Lecture, Kings College, 28 April 2016, available here: https://papers.ssrn.com/sol3/papers.cfm?abstract_id=2786698; see also Neha Vora, Impossible Citizens (2013), at 12: “...an approach to studying citizenship and belonging that attends to the circulation and practice of multiple forms of governance in contemporary nation-states. This approach avoids exceptionalizing particular parts of the world and instead acknowledges that globally and locally circulating vocabulatires of economy, belonging, and rights are assembled, disassembled, and reassembled everywhere.".

${ }^{5}$ R (Miller) v Secretary of State for Exiting the European Union, [2016] EWHC 2768 (admin), 3 November 2016, available at: https://www.judiciary.gov.uk/judgments/r-miller-v-secretary-of-state-for-exitingthe-european-union/

6 See the following links: http://www.abc.net.au/news/2016-11-09/donald-trump-wins-us-electiondefeats-hillary-clinton/8006776; $\quad$ http://www.economist.com/news/united-states/21710012something-between-reaganism-and-frances-national-front-probably-what-expect?fsrc=permar|image3.
} 
charged and contested as that of the 'rule of law' [RoL]. While references to the RoL abound and the concept is arguably one of the most frequently alluded to when debating the foundations and aspirations of a modern legal system, ${ }^{7}$ the term itself continues to remain open-ended, contested as well as burdened with conflicting normative assertions: while it conjures community as well as insists on authority and emphasizes rule-boundedness as well as promises enforceability, it does not say very much outright as to its stakeholders and its constituents, those who give it legitimacy and those who are affected by it. Whose Rule of Law are we speaking of, which values are enshrined in its concrete instantiation in a particular place and time? Which processes of legitimation and execution does it require or presuppose? Which actors are considered central or peripheral to the optimal operation of the RoL? Which norms can the RoL not do without, and what is their place in the RoL's system? Does the RoL require a hierarchy of norms, and does the concept itself allow for an identification of the values for that hierarchy?

The significance of the RoL within the legal (and political) imagination, as numerous attempts to define and conceptualize, ${ }^{8}$ theorize, challenge ${ }^{9}$ and resist it, ${ }^{10}$ have shown, might just as well be its irreducibly ambiguous character. Its slippery nature not only invites both the interpretation from various points of view and the translation between its use in legal, political, socio-economic, historical and anthropological and sociological discourses, it demands them. But, seen through this lens, the 'RoL problem' for law echoes the challenges which other disciplines tend to encounter with 'core' concepts. Imagine asking a philosopher to provide us with a summary regarding the idea of

\footnotetext{
7 See the masterful analysis and overview of approaches by Brian Z. Tamanaha, On the Rule of Law (2004). But, see also the World Bank's inclusion of the RoL as one of "six dimensions of governance" as part of its "Worldwide Governance Indicators Programme": http://databank.worldbank.org/data/databases/rule-of-law.

${ }^{8}$ For a very helpful and insightful guide to competing interventions, see Christopher May, The Rule of Law. The Common Sense of Global Politics (2014), ch. 2 ("Defining the rule of law, between thick and thin conceptions", id., at 33-56.

${ }^{9}$ Katharina Pistor/Antara Haldar/Amrit Amirapu, Social norms, rule of law, and gender reality. An essaay on the limits of the dominant rule of law paradigm, in: Global Perspectives on the Rule of Law 241 (Heckman/Nelson/Cabatingan, eds., 2010), who address the RoL's shortcomings in capturing and theorizing levels of inequality, using women as but one example; see also the critique of the World Justice Forum's 'Rule of Law' index, which prioritizes a limited range of economic and political factors to the detriment of others: Jothie Rajah, 'Rule of Law' as Transnational Legal Order, in: Transnational Legal Orders 340 (Halliday/Shaffer, eds., 2015).

10 See Edward Palmer Thompson, Whigs and Hunters. The Origins of the Black Act (1975), and Alvaro Santos, The World Bank's Uses of the 'Rule of Law' Promise in Economic Development, in: The New Law and Economic Development. A Critical Appraisal 253 (Trubek/Santos, eds., 2006).
} 
'truth'11 or of 'beauty'.12 Or, if we asked a political theorist to define 'order', 13 or a (legal) philosopher to offer a satisfying definition of 'justice'. ${ }^{14}$ Similarly related to these types of questions in the context of the RoL are those which are now raised within the fields of geography, legal geography and spatial studies with regard to 'jurisdiction' and to the 'place of law'.

Several crucial parameters become visible here: on the one hand, scholars in these fields debate the 'horizontal' and 'vertical' situatedness of legal orders while simultaneously emphasizing the contextual embeddedness of the legal architecture in historically evolving political orders and, more particularly, that of law's role in the West's emergence of the nation-state ${ }^{15}$ and the capitalist order. ${ }^{16}$ On the other, the RoL's normative ambiguity, in other words, its slippery assertion of a value system caught up, endorsed and given validity in the constitution and the execution of an institutionalized legal architecture prompts challenge and resistance on various other levels. The RoL both posits and questions normative assertions of a legal order and how and for whom it is established. Who is setting up the RoL, whose values does it serve to represent and protect? As such, the critique of the RoL cannot be sensibly separated from an assessment of the historical and socio-economic context in which a particular instantiation of the RoL is being debated, something which E. P. Thompson so masterfully laid out in the bulk of 'Whigs' that precedes the famous observations on the rule of law at the end of the book, too often cited in isolation from the rest. ${ }^{17}$ In that context, then, it also became visible how the RoL raises significant concerns regarding

${ }^{11}$ Crispin Wright, Truth: A Traditional Debate Reviewed, 28 Canadian Journal of Philosophy 31 (1998).

12 Jennifer McMahon, Beauty, in: The Routledge Companion to Aesthetics, 2nd ed. 307 (Gaut/Lopes, eds., 2005).

13 Nancy Fraser/Axel Honneth, Redistribution or Recognition? A Political-Philosophical Exchange (2003).

${ }^{14}$ John Rawls, A Theory of Justice (1971); Martha C. Nussbaum, Frontiers of Justice. Disability, Nationality, Species Membership (2006); Amartya Sen, Global Justice, in: Global Perspectives on the Rule of Law 55 (Heckman/Nelson/Cabatingan, eds., 2000).

15 Austin Sarat/Lawrence Douglas/Martha Merrill Umphrey, Where (or What) Is the Place of LAw? An Introduction, in: The Place of Law 1 (Sarat/Douglas/Merrill Umphrey, eds., 2006), 2: "[Q]uestions of jurisdiction lead us to consider the very sources and limits of legal authority, and to consider the law's role in the construction of the classical political form of Western modernity: the sovereign nation-state." 16 "Weber's account sees the rule of law as contributing to the rationalization of contemporary capitalist society, but (in a dialectical relationship) also reflecting such rationalization." May, Rule of Law (2014), 34. In that vein, compare David Trubek's seminal analysis: David Trubek, Max Weber on Law and the Rise of Capitalism, Wisconsin Law Review 720 (1972), at 724, 725: “...Weber believed that European law was more 'rational' than the legal systems of other civilizations, that is, it was more highly differentiated (or autonomous), consciously constructed, general, and universal. [...] The failure of other civilizations to develop rational law helped explain why only in Europe could modern, industrial capitalism arise."

17 Edward Palmer Thompson, Whigs and Hunters. The Origins of the Black Act (1975). 
its relation to other formations of 'legal' ordering. One of the key questions in Thompson's analysis concerned the relationship between the 'legal' order with which the newly introduced system, represented by the ominous 'Black Act', was confronted. Rather than presupposing a legal void, the carefully presented analysis made the tension visible and tangible that existed between what was already in place and the more recent superimposition. The recognition of a legal pluralist universe in which a legal positivist order intervenes and with which it will (perhaps forever) stand in tension, is an insight of absolutely crucial significance. When the renowned anthropologist, Sally Engle Merry, published a short article on "Legal Pluralism" in the Law \& Society Review in 1988, its appearance marked an important intervention in an already lively debate, which touched upon the nerve of legal theory right and left. At the outset of her article, Professor Merry observed:

"The intellectual odyssey of the concept of legal pluralism moves from the discovery of indigenous forms of law among remote African villagers and New Guinea tribesmen to debates concerning the pluralistic qualities of law under advanced capitalism. In the last decade, the concept of legal pluralism has been applied to the study of social and legal ordering in urban industrial societies, primarily the United States, Britain, and France. Indeed, given a sufficiently broad definition of the term legal system, virtually every society is legally plural, whether or not it has a colonial past. Legal pluralism is a central theme in the reconceptualization of the law/society relation."18

Looking at the RoL through a legal pluralist lens reveals a complex and constantly shifting and evolving assemblage of actors, norms and processes. Instead of a neatly constituted and institutionalized system of, say, 'checks and balances',19 'constitutional democracy', ${ }^{20}$ and the legality principle, ${ }^{21}$ we are confronted with a living organism, pulsating and shaking, multidimensional and with sensitive nervous fibers, operating at different levels of the political, cultural and socio-economic system. Most importantly, however, the legal pluralist RoL presents us with a methodological challenge. Echoing the challenges that early private-law oriented approaches to comparative law would

\footnotetext{
18 Sally Engle Merry, Legal Pluralism, 22 Law \& Society Review 869 (1988), 869.

19 Compare Federalist Paper No. 51, "The Structure of the Government Must Furnish the Proper and Balances Between the Different Departments", http://avalon.law.yale.edu/18th_century/fed51.asp.

20 Michel Rosenfeld, The Rule of Law and the Legitimacy of Constitutional Democracy, 74 Southern California Law Review 1307 (2001), 1308.

${ }^{21}$ Compare the RoL definition as offered by the World Justice Project, which posits, inter alia, that: "The government and its officials and agents as well as individuals and private entities are accountable under the law." See http://worldjusticeproject.org/what-rule-law.
} 
pose for efforts to elaborate a comprehensive framework for the study of comparative public law, which does not reduce public law to anything 'governmental', done by the state $^{22}$, the legal pluralist perspective on the RoL must seek to decenter the material infrastructure of the state, its institutions and processes as based on constitutional and administrative law.

\section{Legal Pluralism and Its Many Effects}

At the same time, we how may we explain the considerable gap between legal pluralist approaches to the study of the RoL and other contemporary work? Is there a valid concern of the use of a legal pluralist lens leading us too far away from what would otherwise have been the conceptual frameworks to be employed for the task of studying the RoL in a transformed, globalised context? But, which concepts would be adequate today? Which conception, definition or model of the RoL should we take as our reference point and which disciplinary (law, political science, 'governance studies', sociology, anthropology) or subdisciplinary frameworks (comparative, 'global' and 'transnational' constitutional law, 23 'global administrative law', ${ }^{24}$ comparative politics, 'fragmented sovereignties', 'assemblages'25 or Sharma and Gupta's 'anthropology of the

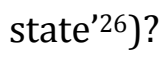

The problem with the opening of the door to contesting voices is that not only is the door never to be shut again, but it also becomes clear how that door can at best only ever have been a curtain, a drapery, a sound-muffling cloth that both blocked the view

22 Konrad Zweigert/Hein Kötz, An Introduction to Comparative Law, 3rd ed. (1996); Jonathan Hill, Comparative Law, Law Reform and Legal Theory, 9 Oxford Journal of Legal Studies 101 (1989); Sunil Khilnani/Vikram Raghavan/Arun K. Thiruvengadam, Introduction: Reviving South Asian Comparative Constitutionalism, in: Comparative Constitutionalism in South Asia 1 (Khilnani/Raghavan/Thiruvengadam, eds., 2013), 11.

23 For an overview of the literature at the time, see Peer Zumbansen, Comparative, Global and Transnational Constitutionalism: The Emergence of a Transnational Constitutional Pluralist Order, 1 Global Constitutionalism 16 (2012).

${ }^{24}$ Benedict Kingsbury/Nico Krisch/Richard Stewart, The Emergence of Global Administrative Law, 68 Law \& Contemporary Problems 15 (2005).

25 Stephen J. Collier/Aihwa Ong (ed.^eds.), Global Assemblages: Technology, Politics, and Ethics as Anthropological Problems (2008).

${ }^{26}$ Aradhana Sharma/Akhil Gupta (ed.^eds.), The Anthropology of the State: A Reader (2005). 
and the ears for what are in fact the manifold cross-relations between mainstream and alternative, centre and periphery, North and South accounts of the RoL and constitutionalism. Such, at least, is the impression we begin to gain when looking beyond the solid and richly stacked library of Western constitutional law and Rule of Law theory. Once we let our gaze wander in the search of references to and analyses of the RoL 'in the Global South', we embark on a journey that is in so many ways experimental. It is neither clear from the outset, where the journey is headed, nor what is expected to be found, discovered - yes, even learned at the end. Similarly, and rather quickly, it begins to dawn on us, that by making the attempt to 'provincialise'27 Western narratives of the RoL and closely situated traditions of comparative and even 'global' constitutional law, ${ }^{28}$ we are at a loss of clearly defining where I am looking and, indeed, for what.

Rejecting a traditional and highly influential North-American and European bias and focus on the part of much 'comparative constitutional law', ${ }^{29}$ scholars from the 'global south', in particular, have been arguing for a widening, if not a reversal of perspective. Scholars such as Rachel Sieder, Javier Couso and Alexandra Huneeus, picking up on the theme of 'judicialization of politics',30 have recently pressed for a legal culture perspective on the already actively studied processes of judicial interventions in different societal transformation processes in Latin America. Sieder and her colleagues argue for a three-fold expansion of the existing analysis by political science, theory and law scholars on the role played by law and legal institutions in Latin America, first, by claiming a particular role of the concept of legal culture to expose the symbolic and discursive dimensions of law, second, by drawing on the 'law and society' movement to

27 Compare Dipesh Chakrabarty, Provincializing Europe. Postcolonial Thought and Historical Difference, 2nd ed. [orig. 2000] (2007).

28 Antje Wiener, Global Constitutionalism: Mapping an Emerging Field. Background paper for the Conference: Constitutionalism in a New Key?, Berlin 28-29 January 2011 (http://cosmopolis.wzb.eu/content/program/conkey_Wiener_Mapping-Field.pdf) (2011).

29 "The newly revitalized field of comparative constitutional law has tended to let Europe and North America and Europe dictate the agenda." Rosalind Dixon/Tom Ginsburg, Introduction: Comparative Constitutional Law, in: Research Handbook on Comparative Constitutional Law 1 (Dixon/Ginsburg, eds., 2011), 1.

30 Compare here Ran Hirschl, The Judicialization of Politics, in: The Oxford Handbook of Law and Politics 119 (Caldeira/Kelemen/Whittington, eds., 2008). See also the contributions to Rachel Sieder/Line Schjolden/Alan Angell (ed.^eds.), The Judicialization of Politics in Latin America (2005). A fascinating study on the interpretive-political space opened up by the judicialization of politics is offered by Philip Liste, Transnational Human Rights Litigation and Territorialized Knowledge: Kiobel and the 'Politics of Space', 5 Transnational Legal Theory 1 (2014). 
render more visible the impact that extrajudicial actors and developments have on the formal legal system, and, third, by contextualizing the 'judicialization of politics' within the concrete developments in Latin America - rather than comparing local instances against an alleged matrix imported from the North. “...judicialization in the developing world unfolds in a context in important ways different from that of developed countries with longer histories of centralization of power." 31

Similarly, the renowned Colombian socio-legal scholar, César Rodríguez-Garavito, recently published a forceful call-to-arms for a new, locally based and locally informed approach to the study of law \& society with regard to the transformations currently underway in a number of countries in Latin America. Lamenting that "Latin American scholars spend an excessive amount of time, resources and energies assimilating, translating and interpreting (or simply 'staying current' with) materials in the North", while with regard to legal theory "[i]n their writings about the law, Latin American authors have a marked predilection for exegesis and commentary without reference to the actual practice of law or, even less, the reality of how law is applied in local contexts", Rodríguez-Garavito concludes, that "[m]any scholars try to explain institutions and legal practices in the region by comparing their realities with ideal types (in a normative sense, that is to say, as superior models) extracted from an uncritical reading of the realities of Europe or the United States." 32 Drawing, on the one hand, on Sousa Santos' image of law as 'a map of misreading', and, on the other, on Diego López' seminal study from $2004^{33}$ and, in particular, López' suggestion to distinguish between (the North as) a "site of production" and (the South as) a "site of reception' for legal theory, legal-political concepts and legal philosophical principles, ${ }^{34}$

31 Alexandra Huneeus/Javier Couso/Rachel Sieder, Cultures of Legality: Judicialization and Political Activism in Contemporary Latin America, in: Cultures of Legality. Judicialization and Political Activism in Contemporary Latin America 3 (Couso/Huneeus/Sieder, eds., 2010), 5.

32 César Rodríguez-Garavito, Remapping law and society in Latin America. Visions and topics for a new legal cartography, in: Law and Society in Latin America. A New Map 1 (Rodríguez-Garavito, ed., 2015), 3, 4.

33 Diego Eduardo López Medina, Teoría impura del derecho. La transformación de la cultura jurídica latinoamericana. Prólogo de Duncan Kennedy (2004), 15-21.

34 López Medina, Teoría impura, at 15: "La filosofía del derecho presenta un grueso blindaje frente a un posible asalto del perspectivismo teórico. De esta forma se genera la impression que la filosofía de derecho son discursos abstractos de alcance global. (...) Ese campo intellectual transnacional en el que los iusteóricos nos hallamos inmersos podría denominarse teoría tansnacional del derecho (TTD)..." [The philosophy of law presents a firm armor front against a possible assault of theoretical perspective. From this form arises the impression that the philosophy of law consists of abstract discourses of global scope. (...) This intellectual transnational camp in which we found immersed the jurisprudes might be called 
Rodríguez-Garavito sets out to propose a 'new legal cartography'. In light of a by now well-routinized practice of studying law (and society) in Latin America through the use of imported and assimilated conceptual approaches and categories, he asks a number of guiding questions:

"How can we escape this trap? How can we overcome the continuing legacy of lawand-development thinking? How can critical scholarly perspectives, from inside and outside the region, foster a horizontal transnational dialogue among equals about law in Latin America? How can we create a community of scholars that produce richer theoretical and empirical analyses, and foster legal practices that deepen democracy, equality, plurality and human rights in Latin America?"35

Among the elements he identifies in the existing and emerging socio-legal scholarship in Latin America to contribute to a more locally oriented analysis and understanding, is the detailed study of different constitutionalist projects in the region, focusing not only on the place of socio-economic rights in many constitutional texts, but on the particular role played by constitutional courts and tribunals in enforcing such rights. Connected hereto and indeed echoing the analysis offered by Sieder and her colleagues is the emphasis on the importance of impact studies regarding the real-world consequences of ambitious constitutional shifts. ${ }^{36}$ Another important application site in this regard is the intensification in courts as well as public debates of the treatment of and the engagement with rights of indigenous and other racially discriminated peoples, brought into the spotlight of wide attention, for example, through the growing resistance against the granting of mining licenses for foreign multinationals and the frequent cases of expropriation and dramatic displacement of affected indigenous communities. ${ }^{37}$ In the

transnational theory of law (TTL)..." [PZ transl.] On p.16, he continues: "La TTD se produce comúnmente en un lugar que me gustaría caracterizar abstractamente come 'sitio de producción'. Un sitio de producción parece ser un medio especial en donde se producen discusiones iusteóricas con altos niveles de influencia transnacional sobre la naturaleza y las políticas del derecho. Los sitios de producción están usualmente afincados en los círculos intelectuales e instituciones académicas de Estados-nación centrales y prestigiosos." And, on p.17, he goes to contrast them with the 'sites of reception': "La contracara des los sitios de producción son los sitios de recepción. Dentro de un sitio de recepción, por lo general, la iusteoría producida allí ya no tiene la persuasividad y circulacíon amplia de la TTD, sino que, por el contrario, uno estaría tentado a hablar major de iusteoría 'local', 'regional', 'particular' o 'comparada'.”

35 Rodríguez-Garavito, Remapping, at 5.

${ }^{36}$ Rodríguez-Garavito, Remapping, at 9.

37 Id., at 11-12. See also the United Nations' "Indigenous Peoples Indigenous Voices Fact Sheet”, 2009 (?), entitled: Indigenous Peoples and Industrial Corporations, available at: http://www.un.org/en/events/indigenousday/pdf/Indigenous_Industry_Eng.pdf. There, it says on p.2.: "Particularly serious challenges to indigenous rights are generated by mega-projects, such as mining, oil, gas and timber extraction, monoculture plantations and dams. The impact of such projects includes 
words of Julian Burger of the University Essex, who authored the 2014 research report on "Indigenous Peoples, Extractive Industries and Human Rights" for the European Parliament's Subcommittee on Human Rights, "Human rights abuses associated with the exploration and exploitation of non-renewable resources include, among others, violation of the right to life, forced displacement and destruction of the environment on which indigenous peoples depend." 38 While these local consequences of foreign direct investment by foreign multinationals in resource exporting regions around the world have long been a central focal point and driver of demands for the sovereign permanent use of natural resources ${ }^{39}$, the problem as described by protagonists and supporters of investor state arbitration is regularly described as one of expropriation - of the corporation through regulatory interventions by the host state. ${ }^{40} \mathrm{An}$ article published in the fall of 2016 in the Harvard Law Review concluded that "one factor driving the continuing conflict between indigenous peoples and natural-resource development relates to power imbalances between two divergent international legal regimes indigenous rights and international investment law - that demand that states act in conflicting ways regarding the same territory and peoples." ${ }^{11}$ Meanwhile, the continued and arguably growing dependency of the global economy on accessing natural resources prompts further efforts in developing a basis for natural resource exploitation

environmental damage to traditional lands in addition to loss of culture, traditional knowledge and livelihoods, often resulting in conflict and forced displacement, further marginalization, increased poverty and a decline in the health of indigenous peoples."

38 Julian Burger, Indigenous Peoples, Extractive Industries and Human Rights, report for the European Parliament's Subcommittee on Human Rights, Strasbourg, 2014, available at: http://www.europarl.europa.eu/RegData/etudes/STUD/2014/534980/EXPO_STU\%282014\%29534980 EN.pdf, at 5.

39 In the words of George Foster, these experiences form "part of a broad, global pattem of encroachment of private commercial interests onto the lands of indigenous peoples, facilitated by national governments, which began long ago and has never stopped." See George K. Foster, Foreign Investment and Indigenous Peoples: Options for Promoting Equlibrium between Economic Development and Indigenous Rights, 33 Michigan Journal of International Law 627 (2012), at 629.

40 OECD Directorate for Financial and Enterprise Affairs, Working Paper on International Investment, "Indirect Expropriation" and the "Right to Regulate" in International Investment Law, September 2004, available here: https://www.oecd.org/daf/inv/investment-policy/WP-2004_4.pdf, highlighting the remaining lack of clarity in distinguishing between 'indirect expropriation' and legitimate, noncompensable regulation: "Scholars recognised the existence of the distinction but did not shed much light on the criteria for making the distinction. This may reflect reluctance to attempt to lay down simple, clear rules in a matter that is subject to so many varying and complex factual patterns and a preference to leave the resolution of the problem to the development of arbitral decisions on a case-by-case basis." (Id., at 910).

${ }^{41}$ See The Double Life of International Law: Indigenous Peoples and Extractive Industries (Developments in the Law), 129 Harvard Law Review (2016), 1755, online at: http://harvardlawreview.org/2016/04/the-double-life-of-international-law-indigenous-peoples-andextractive-industries/ (conclusion). 
within the body of foreign investment law, ${ }^{42}$ arguably without too much concern for the perspective of the displaced peoples affected by the FDI.

How, then, can we study the connections between these dramatic conflicts between different contentions regarding the content of economic and political rights, on the one hand, and the changing perspectives in comparative and 'global' constitutional law, on the other? Which methodological tools are required to make visible the place of the 'RoL' in a much wider space of legal-theoretical and socio-economic contention? An important set of sign-posts can be taken from 'law and development' scholarship in which the assertion of the RoL has always been contested and where scholars have long been stressing the importance of studying the presently offered models of the RoL against a complex and violent history of colonial rule and imperialism. ${ }^{43}$ This scholarship has very productively informed and been in dialogue with work on indigenous rights, legal pluralism and the more recently emerged concept of 'transformative constitutionalism'. 44

These, admittedly crudely preliminary and selective, insights gained from no more than a glimpse at constitutionalism discourses in Latin America through the lens of locally experienced transformations, shaped by local and regional discourses, political and judicial interventions as well as public debates seems, however, to reveal the blind spots of what Diego López Medina calls 'TTD'. In applying a set of constitutional law principles as they were developed in North America and Western Europe as a yardstick against and in comparison to which developments in other parts of the world can be measured, the TTD represents no more than what Medina depicted as an 'abstract discourse of global scope'. What escapes the parameters of such abstract theorizing is the particular nature of what happens locally, and what cannot be studied from the high oxygen-less

\footnotetext{
42 Jorge E. Viñuales, International Investment Law and Natural Resource Governance. E15Initiative. Geneva: International Centre for Trade and Sustainable Development (ICTSD) and World Economic Forum, 2015, available at http://e15initiative.org/wp-content/uploads/2015/07/Extractive-VinualesFINAL1.pdf.

43 David Trubek, Toward a Social Theory of Law: An Essay on the Study of Law and Development, 82 Yale Law Journal 1 (1972). See also the insightful critique of the continuities of colonial understandings of the elite being in charge of the rule of law by Jorge L. Esquirol, The Latin American Tradition of Legal Failure, 2 Comparative Law Review 1 (2011), 9.

44 Natalia Angel-Cabo/Domingo Lovera Parmo, Latin American social constitutionalism: courts and popular participation, in: Social and Economic Rights in Theory and Practice. Critical Inquiries 85 (Alviar García/Klare/Williams, eds., 2015).
} 
altitude of theoretical discourses alone. And it is the resistance against such abstract and, by consequence, hegemonizing theorizing which informs and drives a lot of critical, local scholarship and which experts in the Global North and the West need to engage with. ${ }^{45}$ As the $21^{\text {st }}$ century promises more geopolitical change and North-South and South-South shifts, traditions of American and European constitutionalism are not likely to provide the all-sufficient conceptual and theoretical guidelines. ${ }^{46}$

Similar impulses to rethink, to re-localise and to critically reassess the Western influence on shaping 'global' and 'comparative' constitutional law as the taken-forgranted frameworks for thinking about the Rule of Law also come from Asia. Not only are important and groundbreaking judicial developments widely discussed as matters of not merely 'local' concern ${ }^{47}$, but what becomes visible is a far-reaching critique of many of the inherited assumptions regarding the purpose and scope of comparative constitutional law:

"The dominant players in the field of comparative law extolled the virtues of a 'functionalist' approach which would use comparative models and examples to solve problems and arrive at practical solutions. It was therefore natural that comparative constitutional law would also be affected by this overall approach.

45 See, for example, the contributions to the important collection of essays resulting from a collaboration among scholars in Colombia and the United States: Helena Alviar García/Karl Klare/Lucy A. Williams (ed.^eds.), Social and Economic Rights in Theory and Practice. Critical Inquiries (2015). See also two recent, well-informed overviews of theory developments in Latin America from Germany, one from the director at the Max Planck Institute in Heidelberg (Armin von Bogdandy, Ius Constitutionale Commune en América Latina - Beobachtungen zu einem transformatorischen Ansatz demokratischer Verfassungsstaatlichkeit, 75 Heidelberg Journal of International Law (ZaöRV - HJIL) 345 (2015), and one from a young legal scholar at the Viadrina University in Frankfurt (Oder): Heiner Fechner, Neue Rechtstheorie(n) in Lateinamerika. Vom Alternativen Recht zum Emanzipatorischen Rechtspluralismus, 48 Kritische Justiz 446 (2015).

46 Jean Comaroff/John L. Comaroff, Theory from the South: Or, How Euro-America is Evolving Toward Africa (The Radical Imagination) (2011); Dipesh Chakrabarty, Provincializing Europe. Postcolonial Thought and Historical Difference, 2nd ed. [orig. 2000] (2007); Hamid Dabashi, Can Non-Europeans Think? (With a foreword by Walter Mignolo) (2015). See also Sunil Khilnani/Vikram Raghavan/Arun K. Thiruvengadam, Introduction: Reviving South Asian Comparative Constitutionalism, in: Comparative Constitutionalism in South Asia 1 (Khilnani/Raghavan/Thiruvengadam, eds., 2013), 10-11: "Even as scholars have termed this era 'the heyday for scholars of comparative constitutional law and politics', they are quick to acknowledge that certain 'foundational, ontological, epistemological and methodological questions concerning the field's purpose, scope and nature' still need to be addressed."

47 Rehan Abeyratne/Nilesh Sinha, Insular and Inconsistent: India's Naz Foundation Judgment in Comparative Perspective, 39 Yale Journal of International Law (online) 74 (2014); Sujit Choudhry, How to Do Comparative Constitutional Law in India: Naz Foundation, Same Sex Rights, and Dialogical Interpretation, in: Comparative Constitutionalism in South Asia 45 (Khi-lnani/Raghavan/Thiruvengadam, eds., 2013), 46: "Is the Indian Constitution merely a legal means to implement rights, that exist independently and apart from the Indian constitutional order, in universal principles of liberal political morality?". 
Subsequently, comparative law also developed a more 'universalist' rationale, which posits that a community's conceptions of law, politics, and justice could be enriched by studying foreign experiences." ${ }^{48}$

Resisting the circular referral to the 'usual suspects' in global/comparative constitutional law - including "Canada, Israel, Germany, New Zealand, South Africa, the United Kingdom, and the United States" 49 - locally informed efforts of giving voice to alternative, non-hegemonic and non-mainstream lines of constitutional law development are making the map more detailed, but at the same time more messy and more incoherent. "The appellation 'South Asia' constitutes variegated feats of colonial and imperial geographies, subsequently reinforced by the time-places of the Cold War and disciplines curiously names as 'area studies'. [...] ...given the 'genius' of colonial rule to produce 'severely divided societies suffused with 'political' constructions of 'ethnicity', questions concerning the enunciation of basic human rights of religious, cultural, and linguistic minorities haunt forms of 'South Asian constitution-making and development." 50 For Upendra Baxi, this assessment prepares the ground for a call for "a new postcolonial nomenclature", which is informed by a fundamental recognition of the colonial heritages that influence constitution-making:

\begin{abstract}
"To state the obvious, SAC [South Asian Constitutionalism] founding choices remain ambivalent. Choosing forms of governance is never an endeavor at wiping the slate of history clean! More to the point, perhaps, are acts of re-writing that may render a little more legible some future histories of SAC. And there is 'more' to governance than entailed in formulation of constitutional texts, read merely as exercises in miming available EuroAmerican constitutional models!"51
\end{abstract}

\title{
III. The Rule of Law as a Mediator of Entitlements: North, South, or Transnational?
}

Upendra Baxi's critique of a tradition that, in benign neglect of the underlying colonial

\footnotetext{
${ }^{48}$ Khilnani et al, Introduction, 11.

${ }^{49}$ Choudhry, How to Do, at 47.

50 Upendra Baxi, Modelling 'Optimal' Constitutional Design for Government Structures. Some Debutant Remarks, in: Comparative Constitutionalism in South Asia 23 (Khilnani/Raghavan/Thiruvengadam, eds., 2013), 24, 25.

51 Baxi, Modelling, 29.
} 
heritage which continues to exert its stronghold via constitutional design export, foreign direct investment and trade rules, is not merely directed against constitutional principles of Western design. More specifically, the target is the narrowing of a horizon of possibilities that results from having accepted the idea of a constitution and of constitutionalism as "governance machines", through which particular and externally imposed incarnations of economic and political order are inscribed into a country's DNA. ${ }^{52}$

This observation echoes the concerns raised in the context of clashing entitlements and rights between foreign direct investment protagonists and local indigenous communities, mentioned earlier. At the centre of that confrontation are competing interpretations of the economic orientation of the constitutional text as it serves as the basis for a balancing of individual and collective rights. In 2008, the indigenous rights scholar, Lillian Aponte Miranda pointed to

\begin{abstract}
"a marked increase in the number of natural resource extraction projects, often executed through the joint efforts of states and transnational business enterprises, [which] has aggravated the threat to indigenous peoples' ability to control their traditional lands and resources.4 The execution of natural resource extraction projects typically implicates indigenous peoples' land tenure systems and formal state law regarding the ownership and allocation of the territory at issue. Thus, these projects often force an interface between the distinct legal orders of indigenous peoples and the state."53
\end{abstract}

This example of clashes between a property rights-based understanding of international investment law, on the one hand, and indigenous uses and traditional title to land, on the other, attains further poignancy in that it illustrates the point made earlier about Weber. For Weber already it was clear that a legal order does neither emerge nor stand in isolation from the socio-economic developments that are going on around it. And, as scholars in the newly revived tradition of Weber-inspired economic sociology of law suggest, there is today a pressing urgency to unpack the law's connection to and its role

\footnotetext{
52 Baxi, Modelling, 28.

53 Lillian Aponte Miranda, Uploading the Local: Assessing the Contemporary Relationship Between Indigenous Peoples' Land Tenure Systems and International Human Rights Law Regarding the Allocation of Traditional Lands and Resources in Latin America, 10 Oregon Review of International Law 419 (2008), 421.
} 
in fostering certain models of economic governance through state institutions. ${ }^{54}$

As much of Western legal and political theory remains focused on the analysis of the rise of the nation state, the role and legacies of civil revolutions and the fate of the (European, Westphalian) nation-state in the $21^{\text {st }}$ century, post-colonial scholars have been drawing different historical lineages in the construction of political identity and sovereignty between the times of European colonial expansion and the present. ${ }^{55}$ The repercussions on law and legal theory are only slowly becoming fully accessible. 'Postcolonial' legal thought, if we were to apply this label to such an undertaking, is impossible to define. Its very nature, which comes into focus only by looking at different critical approaches in a range of disciplines in the humanities at the same time, appears thus to defy a unifying definition. What becomes visible then, are complex, multi- and interdisciplinary efforts to resist, unpack and challenge universalizing narratives, concepts and explanations as well as objectifying accounts and streamlining historical narratives. Law and legal scholarship have been playing an intriguing part in such efforts. With globalization having had unearthing effects on the imaginary and conceptual ties between the Western state and the idea of modernity ${ }^{56}$, those on law and politics and their particular nexus with the state have been considered as being just as significant. ${ }^{57}$

What such accounts tend to treat with less emphasis, however, is the 'outside' of the

\footnotetext{
${ }^{54}$ See, inter alia, Sabine Frerichs, From Credit to Crisis: Max Weber, Karl Polanyi, and the Other Side of the Coin, 40 Journal of Law and Society 7 (2013); Richard Swedberg, The Case for an Economic Sociology of Law, 32 Theory and Society 1 (2003), and the fantastic analysis by the feminist and post-colonial scholar, Prabha Kotiswaran, Do Feminists Need an Economic Sociology of Law?, 40 Journal of Law and Society 115 (2013).

55 Eve Darian-Smith/Peter Fitzpatrick, Laws of the Postcolonial: An Insistent Introduction, in: Laws of the Postcolonial 1 (Darian-Smith/Fitzpatrick, eds., 1999).

56 Arjun Appadurai, Modernity at Large. Cultural Dimensions of Globalization (1996), 19: "Nation-states, as units in a complex interactive system, are not very likely to be the long-term arbiters of the relationship between globality and modernity."

57 Thus goes the standard account among many public lawyers, sociologists and political scientists. See, e.g., Stefano Battini, The Globalization of Public Law, 18 European Review of Public Law 27 (2006); Philip J. Cerny, Globalization and the Changing Logic of Collective Action, 49 International Organisation 595 (1995), and Ian Clark, Globalization and International Relations Theory (1999), 4: "The emerging literature about globalization is characterized by marked diversity... However, as a broad introductory generalization, it can be said that it is very much engaged in a debate about the retreat or resilience of the state. [...] Viewed in these polarized terms, the state is either the object or the subject of globalization." Placing this against the background of a liberal theory, that is based on the distinction between public and private and the national and international, is Jürgen Habermas, The Postnational Constellation, trans. by Pensky (2001), ch. 1.
} 
story, the 'other', the alternative perspective on the described trajectory. This kind of Eurocentrism has thus become object of various critical attacks, ${ }^{58}$ and legal scholarship's engagement with postcolonial studies must be seen, at least in those quarters where it is occurring, as both irreversible and transformative. ${ }^{59}$ Meanwhile, the implications of postcolonialism on the study of law are as diversified as the field, the idea, the conceptions (of postcolonialism) themselves. In the legal field with the more notable, if still marginal ${ }^{60}$ engagement with postcolonialism and 'third world critical historiography, international law, ${ }^{61}$ a very productive critique has started to take hold in a number of different subfields - ranging from human rights to international trade, or from investment to environmental law.

In two powerful works of the last few years, the authors have deliberately and consciously placed their analysis of the RoL in both conceptual-methodological as well as historical-political contexts. Studying Sundhya Pahuja's monographic treatment, 'Decolonising International Law', ${ }^{62}$ we are offered a razor-sharp analysis of the abyss between the paper-form and the real-world impact of the legal forms which accompanied the transition of ex-colonized nations into the formal status of 'sovereign and equal' members of the United Nations. Pahuja bookends her scrutiny of the rights of passage from colonization into sovereign state-hood with a series of reflections about the process through which a certain power constellation comes under law and is, in other words, 'legalized'. In that regard, Pahuja argues at the beginning of her book that “...the 'universalisation' of international law [...] was not the neutral inclusion of all peoples within the international legal order, but rather a process by which a particular

58 See, e.g., the work by Boaventura de Sousa Santos, The Processes of Globalisation, Eurozine http://www.eurozine.com/pdf/2002 (2002); see also the excellent collection and commentary by William Twining, Human Rights, Southern Voices. Francis Deng, Abdullahi An-Na'im, Yash Ghai and Upendra Baxi (2009).

${ }^{59}$ Eve Darian-Smith/Peter Fitzpatrick, Laws of the Postcolonial: An Insistent Introduction, in: Laws of the Postcolonial 1 (Darian-Smith/Fitzpatrick, eds., 1999), at 1: "It is by now close to a truism in the literature of postcolonialism, and elsewhere, that European or Western identity is constituted in opposition to an alterity that it has itself constructed."

60 James T. Gathii, TWAIL: A Brief History of Its Origins, Its Decentralized Network, and a Tentative Bibliography, 3 Trade, Law and Development 26 (2011).

61 Antony Anghie, Colonialism and the Birth of International Institutions: Sovereignty, Economy, and the Mandate System of the League of Nations, 34 N.Y.U. J. Int'l L. \& Pol. 513 (2002); see also Jochen von Bernstorff, German International Law Scholarship and the Postcolonial Turn, EJIL Talk! (Blog of the European Journal of International Law), 7 January 2015, available at: http://www.ejiltalk.org/germaninternational-law-scholarship-and-the-postcolonial-turn/.

62 Sundhya Pahuja, Decolonising International Law. Development, Economic Growth and the Politics of Universality (2011). 
form of socio-political organization was normalized, even as difference was seemingly accommodated by the international community." 63 The RoL is identified as playing a crucial role in this process, as it provides the powerful master category to capture not only the descriptive acknowledgment and endorsement of an emerging and in itself unquestionably justified 'international rule of law', but also the prescriptive proposition that the RoL encapsulate the political-organisational decisions necessary for 'development'64 - certainly another concept, as will become clear over the course of Pahuja's study, what has been high-charged with conflicting assessments of means and ends. A central finding of Pahuja's book is her astute observation that this normalization (in the form of a legally effectively neutralized co-existence of powerful and powerless states) occurred through law, through the generation of 'rights' and the articulation of claims as 'legal' ones. Echoing this observation at the start of her book, her concluding chapters bring the the historical-critical analysis together in a sobering account of the seemingly unstoppable triumph march that the "rule of law" had experienced both post1945 and post-1990. Whereas, however, at the end of World War II and during the concurring struggles of formerly colonized nations to define their however meager role at the table of the international community, the RoL was invoked as a principle of desirable political (international order), its invocation since the 1990s came with a distinct association of the RoL with the actual historical 'achievement' of Western liberalism, human rights and democracy. ${ }^{65}$ The end of the Cold War came to provide the historical moment for a long-harbored normative closure: human rights could and, indeed, should now be defended, fought for and fought over in every corner of the world, now that their previous ideological ambiguity had given way to universal recognition. ${ }^{66}$ With the overcoming of its ideological subtexts at the time of the cold war, human rights were now rid of all ideology - they were, in other words, "universally true" and, by implication, free from and immune to any possible contestation. ${ }^{67}$ Meanwhile, the RoL becomes entrenched as development doctrine, mantra and goal when it is rhetorically employed to link the imagined international community to the

\footnotetext{
63 Id., at 5-6.

64 Id., at 6.

65 Id., at 178-9.

66 Id., at 180.

67 Id.
} 
individuals living (and justifiably enjoying a "right to democracy"68) within states rather than being the governing principle for the relationship between states. ${ }^{69}$ As liberal international relations (IR) scholars such as Anne-Marie Slaughter zero in on the internal governance structures of the state, the shift from a world of sovereign states to that of a world community as agent of scrutinizing, protecting as well as, eventually, disseminating and promoting state-internal democratic governance becomes decisive. ${ }^{70}$ The particular Western, if not U.S.-driven, experience of institutionalized democratic market governance becomes the unquestioned blue-print for the Rule of $\operatorname{Law}^{71}$ as transnational principle and as justification for an ever-accelerating and expanding managerialist protection machine. ${ }^{72}$

Professor Pahuya's award-winning analysis addressed the "instability of international law" at a time, where the world order had become increasingly and perhaps irrevocably fragmented and contested. Bringing together a number of critical strands of international legal thought - from international economic law ${ }^{73}$ to post-colonialist 'third world approaches to international $\operatorname{law}^{\prime 74}$ for a convincing deconstruction of the international-universalist human rights and RoL imaginary, she offered significant assistance to concurring and since emerging efforts of recasting the conceptual and legal framework of the global order - and, remarkably - with the RoL at its center.

The second landmark study which provided us with an unparalleled succinct critique of the foundations, justifications and operations of the RoL in context was written by

\footnotetext{
68 Thomas Franck, The Emerging Right to Democratic Governance, 86 American Journal of International Law 46 (1992), 49.

69 Id., at 182.

70 Id. See Anne-Marie Slaughter, International Law in a World of Liberal States, 6 Eur. J. Int'l L. 1 (1995); and: Jose E. Alvarez, Do Liberal States Behave Better? A Critique of Anne-Marie Slaughters Liberal Theory of International Law, 12 Eur. J. Int'l L. 183 (2001).

${ }^{71}$ Id., at 183.

72 For a cutting interpretation from a feminist-legal-theory perspective, see Anne Orford, Muscular Humanitarianism: Reading the Narratives of the New Interventionism, 10 Eur. J. Int'l L. 679 (2003); see, equally, her masterful study of the U.N.'s evolving role as actor in a managerialist enterprise of 'getting the job done': Anne Orford, International Authority and the Responsibility to Protect (2011).

${ }^{73}$ M Sornarajah, Power and Justice:Third World Resistance in International Law, 10 Singapore Yearbook of International Law 19 (2006); James Thuo Gathii, Third World Approaches to International Economic Governance, in: International Law and the Future 255 (Falk/Rajagopal/Stevens, eds., 2008).

${ }^{74}$ Antony Anghie, Imperialism, Sovereignty and the Making of International Law (2005); Obiora Chinedu Okafor, Critical Third World Approaches to International Law (TWAIL): Theory, Methodology, or Both?, 10 International Community Law Review 371 (2008); Ruth Buchanan, Writing Resistance Into International Law, 10 International Community Law Review 1 (2008).
} 
Jothie Rajah. Rajah's book ${ }^{75}$ offers an inside view into the life of the RoL in the context of post-1965 Singapore and it is this context which is unfolded in its historical, political, economic, legal and discursive dimensions. Through an amazingly close reading of various pieces of Singaporean laws and regulations, Professor Rajah's study achieves a unique multiplication of our perspective on and understanding of the RoL. In each invocation of the RoL by the Singaporean government, its long-time head of state or its various governmental spokespersons, Rajah makes us see the constitutive role of the principle by, on the one hand, invoking an external, non-Singaporean tradition, while extinguishing, invisibilizing and 'silencing' pre-existing Singaporean legal traditions, on the other. ${ }^{76}$ The "RoL" functions both as invocation of and reverence to the British Common Law tradition of Dicey and Co. and as governing principle of the here and now of Singapore's executive state of necessity. ${ }^{77}$

Given the immense presence and importance of the 'RoL' in Singapore's political discourse, the discourse itself becomes the focus of analysis. It is through language, that power is constituted, divided, denied. Echoing the way that late $19^{\text {th }}$, early $20^{\text {th }}$ century legal scholars set out to deconstruct the allegedly value-neutral and objective nature of legal terms ${ }^{78}$, Rajah continues this line of inquiry into the work of Foucault and thus is able to focus specifically on the dimensions of historical specificity and the relationship between legal language/speech and power. ${ }^{79}$ Through the course of case studies pertaining to Singaporean laws on vandalism, press freedom, the legal profession, religious practices and the public order, Rajah's analysis follows the state's and its various regulatory bodies' discursive mapping deep into the daily life of regulatory practices and is thus able to reveal the life between the textual nature of the 'RoL' and its society-and reality-shaping operations.80 Ultimately, the RoL to which the author by self-declaration - remains sympathetic, ${ }^{81}$ has been proven to have achieved the opposite from what we (might) have been associating it with - with the Singaporean

\footnotetext{
75 Jothie Rajah, Authoritarian Rule of Law. Legislation, Discourse and Legitimacy in Singapore (2012).

76 Id., at $35,37$.

77 Id., 39, 42ff, 51. See also id., at 267: “...arguments of exceptionalism and the trope of Singapore's perpetual territorial vulnerability."

78 Just see the account in Neil Duxbury, Patterns of American Jurisprudence (1995).

${ }^{79}$ Rajah, note 14 , at 61.

80 Id., at 223.

81 Id., at 53: “...I ought to declare my own normative inclinations towards a 'rule of law' that protects and upholds political liberalism."
} 
state effectively having achieved "the reconfiguration of the profoundly liberal concept of the 'rule of law' into an illiberal 'rule by law' through the state's manipulation of legislation and public discourse." 82

Rajah's study has the immeasurable value of providing us with both an illustration and a counter-example of the nexus, described by Pahuja, between the citizens' alleged 'right to democratic governance' and the international rule of law as governing principle between these citizens and the international community - bypassing the sovereign states and their (rightful, under public international law) claims to govern their internal affairs. Whereas in Pahuya's account, we are directed towards a critique of the Western neo-liberal invocation of the Rule of Law as a free pass to intervene in the affairs of Slaughter's 'non-liberal states' - all in the name of the RoL - , Rajah dives deep into just these internal affairs in order to trace the myriad ways in which an illiberal State - all in claiming the need to adhere to the inexorably global and universally validified rule of law - can instrumentalize the RoL to authoritarian effects. What Rajah provides us with, then, is not a further proof of why Slaughter's bypassing of state government in order to bring the happy spells of democratic governance directly to the people. Instead, we can see how the state (in this case Singapore) is doing exactly what the World Bank, the 'coalition of the willing' or other zealous RoL advocates have been doing - internally and externally. While these are invoking the RoL in its pure transcendent (nonsensical ${ }^{83}$ ) form while, in truth, disembedding it from a real world of inequality and post-colonial blithe, in which the declaration of sovereign equality is a far cry for most, the others (such as the Singaporean state) call on the RoL in order to justify the repression of local claims in the name of defending externally resonant rights and principles. As the normative difference between the international community and its small circle of (militarily) persuasive spokespeople and authoritarian governments becomes elusive, what begins to emerge is an ever clearer and more fully accentuated picture of a fragmented yet fully operational holding structure of transnational managerialism. Such managerialism has been manifesting itself in various forms - ranging from 'humanitarian intervention' to 'economic' or 'technical assistance' - while in each case the pertinent justificatory basis has been a rhetoric of necessity and efficiency. The

82 Id., at 267.

83 Felix Cohen, Transcendental Nonsense and the Functional Approach, 35 Columbia Law Review 809 (1935). 
displacement of a much more multilayered, eternally open-ended deliberation about competing and conflicting values by a more output-oriented rationality has significant consequences for the ability of carrying out a political debate through the means of law and legal language. Expert language, something we already encountered in our identification of the powerful effect of indicators as displacing the RoL as actor behind the numbers - invokes 'progress' in international economic development ${ }^{84}$, 'stability' and 'security' in the context of national survival ${ }^{85}$, 'human suffering' to justify military intervention ${ }^{86}$ or 'modernisation' in the case of FDI-related economic liberalization and urban transformation policies. ${ }^{87}$ By consequence, it fills the gap that an elusive hope for global political deliberation has left. In a recent book, David Kennedy offers a sobering analysis of the increasingly hermeneutically closed, self-referential language regime that 'experts' (lawyers, economists, political scientists) have been making available for amenable use for every possible 'crisis'. "Expertise - economic expertise, scientific expertise, legal expertise, social and political expertise, institutional and managerial expertise, expertise in the lessons of history and the universal practicalities of everyday life - fills the bill. Those who exercise the powers of expertise rarely think they are 'governing the world'. Their mandate and project is always far more specific, their language more universal. As a result, their powers remain obscure, the opportunity to identify and contest their rulership vanishing point rare." 88 What makes the power of expert language so pervasive and at the same time so elusive from the point of view of political agency, is the matter-of-factness in its ascertainment vis-à-vis 'problems' seeking a solution. "Although we might come to see the situation as driven by power politics, geostrategic interests, regional rivalries, or historic grievance, these also need to be articulated. They are also made real - or not - through practices that confirm the analytics. Such modes of interpretation and methods of engagement are developed,

\footnotetext{
84 Pahuja 2011.

85 Jothie Rajah, Authoritarian Rule of Law. Legislation, Discourse and Legitimacy in Singapore (2012); see also Jothie Rajah, 'Rule of Law' as Transnational Legal Order, in: Transnational Legal Orders 340 (Halliday/Shaffer, eds., 2015).

86 Orford 2003; Martti Koskenniemi, 'The Lady Doth Protest Too Much'. Kosovo, and the Turn to Ethics in International Law, 65 Modern Law Review 159 (2002); Andreas L. Paulus, The War Against Iraq and the Future of International Law: Hegemony or Pluralism?, 25 Michigan Journal of International Law 691 (2004).

87 Priya S. Gupta, Judicial Constructions: Modernity, Economic Liberalization, and the Urban Poor in India, 42 Fordham Urban Law Journal 25 (2014).

88 David Kennedy, A World of Struggle. How Power, Law and Expertise Shape Global Political Economy (2016), 18.
} 
deployed, and defended in specialized terms." 89

\section{Today's Global Rule of Law: Governance by Drones and Numbers?}

What can be summarized at this point, by way of conclusion? There is little doubt today as regards the centrality of RoL assertions in global governance programmes, but at the same time the striking number of contestations, be that on the conceptual or the empirical level, underscores the urgency of further and also differently situated investigation. What the work by scholars cited in the preceding overview illustrates is a pressing need for approaches that critically acknowledge and draw on legal-theoretical and post-colonial scholarship in order to decenter and relativize an otherwise too narrowly shaped investigation into the past and future of a heavily strained concept. The legal pluralist engagement with the RoL might point into a promising direction here. Rather than confirming the cliché of an emerging transnational regulatory order that dethrones the nation-state, makes a mockery of state-based, governmental sovereignty and adopts an overly permissive stance as to what counts as 'law', hereby allegedly treating soft and hard, informal and formal law alike, the above analysis has confirmed something altogether different. Instead of heralding the end of the state and (its) law, the legal pluralist lens has begun to make visible the many local instantiations of legal-regulatory regimes in states of transformation. Pahuja's study, but even more particularly the analysis offered by Rajah, offered us a convincing testimony of the battle over the rule of law 'on the ground', in very concrete and complex, historically shaped and presently evolving socio-economic and geopolitical settings. As we continue to further study the ROL's continuing diffusion and transformation in the areas of technical warfare ${ }^{90}$ and quantification, ${ }^{91}$ questions of local perspective, input and contestation will become ever more important.

\footnotetext{
${ }^{89}$ Id., at 110.

${ }^{90}$ John Kaag \& Sara Kreps, Drone Warfare (2014).

91 The World of Indicators. The Making of Governmental Knowledge through Quantification (Richard Rottenburg, Sally E. Merry, Sung-Joon Park and Johanna Mugler eds., 2015).
} 